\title{
Demokratska tranzicija i izborni sistem u Bosni i Hercegovini: ideje za jačanje predstavničke funkcije Parlamentarne skupštine Bosne i Hercegovine
}

\author{
Elmir Sadiković \\ Vanredni profesor \\ Fakulteta političkih nauka Univerziteta u Sarajevu \\ elmir.sadikovic@fpn.unsa.ba
}

Sažetak: U višestoljetnom razvoju parlamentarizma i predstavničke demokratije parlamenti su predstavljali ključne institucije borbe za demokratiju i ljudska prava. Uloga parlamenata je posebno značajna u zemljama postsocijalističke tranzicije koje nemaju dugu demokratsku tradiciju. Parlamentarna skupština Bosne i Hercegovine čini centralnu instituciju predstavničke/parlamentarne demokratije u Bosni i Hercegovini. Osobina neposredne povezanosti parlamenta i građana instituciji Parlamentarne skupštine Bosne i Hercegovine daje poseban i veći demokratski značaj od drugih institucija političke vlasti. Iskustva drugih država pokazuju da su za upostavljanje i funkcionisanje demokratskog i uticajnog parlamenta potrebne odgovarajuće društveno-ekonomske, političke i kulturne pretpostavke, kao što su: društvena homogenost u pogledu temeljnih vrijednosti, razvijeno civilno društvo, te odgovarajući stepen konsenzusa i integralnosti unutar paralementarnih stranačkih elita. U kojoj mjeri je Parlamentarna skupština Bosne i Hercegovine učinkovita u ostvarivanju predstavničke i nadzorne funkcije? Kako ostvaruje funkciju legitimnosti i učinkovitosti u donošenju zakona i rješavanju društvenih konflikata? Da li je Parlamentarna skupština Bosne i Hercegovine kao najviši zakonodavni organ stvarni nosilac parlamentarne suverenosti? Kakva su iskustva razvoja parlamentarizma i predstavničke demokratije u postdejtonskom političkom razvoju države Bosne i Hercegovine? To su osnovna pitanja koja su predmet elaboracije u ovom radu. Obzirom da političke institucije oblikuju i političku kulturu, cilj ovog rada je i dopuniti određene prijedloge za izmjenu izbornog zakonodavstva kako bi Parlamentarna skupština Bosne i Hercegovine učinkovitije ostvarivala ustavne nadležnosti i svoju demokratsku funkciju.

Ključne riječi: Bosna i Hercegovina, politički sistem, Parlamentarna skupština Bosne i Hercegovine, parlamentarizam, izborni sistem

\section{Parlament i predstavnička demokratija}

Evolucijom evropskih monarhija kroz demokratske reforme i revolucije parlament se kao predstavničko tijelo građana, postepenim ustavnim unapređenjem njegovih prava, na temelju recepcije narodnog suvereniteta, tokom 18. 19. i 20. stoljeća konstituira kao centralna institucija državne moći 
i jedina suverena vlast u državi. U višestoljetnom razvoju parlamenti su postepeno evoluirali od savjetodavnih tijela u moderne legislative sa suverenim ovlaštenjima da donose zakone. ${ }^{1}$ Svi demokratski politički sistemi imaju zakonodavna tijela izabrana na općim, slobodnim izborima i formalno odgovorna građanima. Gotovo univerzalna prihvaćenost zakonodavnih tijela "ukazuje na činjenicu da u modernom svijetu legitimna vlast mora formalno da sadrži i komponentu predstavništva naroda." (Almond, 2009:138) Parlamenti (fr. parler - govoriti) kao zakonodavna tijela povezuju društvo sa pravnom strukturom vlasti u državi. Oni su suštinski instrument predstavničke demokratije. Parlamenti postoje i u autoritarnim režimima. Međutim, demokratsku ulogu ostvaruju samo u liberalnim demokratijama. Svi demokratski parlamentarni politički sistemi se zasnivaju na vrijednostima liberalizma, koji je ideološki oblikovan kao “...izraz vjerovanja u ograničenu vlast, a suština demokratije kao privrženost predstavničkoj narodnoj vladavini zasnovanoj na slobodnim izborima, općem pravu glasa i političkoj jednakosti." (Fejzić, 2016:43). Termin parlamentarizam je sinonim za parlamentarnu, odnosno predstavničku demokratiju, parlamentarni sistem i režim parlamentarne vlade. Za zakonodavna tijela se često koriste različiti izrazi, kao što su skupština, kongres ili parlament. Međutim upotreba navedenih naziva u političkoj teoriji implicira različito značenje i ukazuje na posebne tipove zakonodavnih tijela i političkih sistema. ${ }^{2}$ Skupštine su skupine osoba koje se okupljaju radi neke konkretne svrhe. Ukoliko je ta svrha politička i na nekoj razini prema karakteru zakonodavna, tada možemo govoriti o skupštini kao zakonodavnoj instituciji. U parlamentarnim političkim sistemima izvršnu vlast bira (imenuje) zakonodavno tijelo, a izvršna vlast odgovara zakonodavnom tijelu tokom cijelog mandata. Stoga se o zakonodavnim tijelima u parlamentarnim političkim sistemima najčešće govori kao o parlamentima. Kongresi sa druge strane predstavljaju posebne tipove zakonodavnih tijela. Obično se javljaju u predsjedničkim političkim sistemima (SAD), u kojima se izvršna i zakonodavna vlast biraju neovisno i nijedna nema moć smijeniti drugu, osim u posebnim okolnostima. (Caramani, 2013:122 i 123) Parlamenti, kongresi ili skupštine su u pravilu političke institucije sa zakonodavnim ovlaštenjima i na nacionalnom nivou predstavljaju jedinu suverenu vlast u državi. Princip izražavanja

\footnotetext{
${ }^{1}$ Velika povelja slobode (Magna carta libertatum) iz 1215. godine, kojom je ograničena arbirtrana vlast kralja, javlja se kao izvornik moderne ustavnosti i koja će u dugom historijskom procesu dovesti do prvog engleskog Parlamenta 1265. godine i ustavne vladavine u 17. stoljeću. Vidi: Sadiković, E. (2019). Subnacionalni konstitucionalizam i demokratija. Fakultet političkih nauka. Sarajevo. str. 13.

${ }^{2}$ Političke sisteme prema obliku državne vlasti klasificiramo na predsjedničke, parlamentrane ili skupštinske/konventske. Ta klasifikacija se zasniva na odnosu izvršne i zakonodavne vlasti.
} 
narodne volje kroz parlament postao je "temeljni aksiom liberalne demokratije.” (Haggue i Harrop, 2014:391) Povezivanjem građana i institucija vlasti parlament osigurava legitimaciju cijelog politčkog sistema. To ne znači da je svaki politički sistem koji ima parlament demokratski, ali je borba za demokratiju uvijek bila vezana za određeni parlamentarni uticaj. Drugim riječima, nema demokratije bez parlamenta i parlamentarizma kao njegovog dinamičkog oblika postojanja. Parlamentarizam u širem smislu označava politički sistem u čijem središtu stoji parlament kao centralna i najvažnija institucija predstavnika naroda, u kojoj se vode razumne rasprave i donose najvažnije političke odluke. Pojam parlamentarizma je u savremenom vremenu vezan za brojne dileme i kontroverze. U genezi svog razvoja parlamentarizam nije nastao kao izraz historijske zakonitosti, već je rezultat višestoljetne intelektutalne i političke borbe liberalnih mislilaca i društvenih pokreta za slobodu, jednakost, ljudska prava i ograničenje političke vlasti.

\section{Struktura i osnovne funkcije parlamenta}

Parlament kao osnovna institucija liberalne i demokratske politike svoj značaj prevashodno izvodi iz svoje predstavničke funkcije. Artikulacijom interesa naroda parlament predstavlja građane prema državi, ali i državu prema građanima. Pored predstavničke, klasične funkcije parlamenta u sistemima podjele vlasti su zakonodavna (usvaja zakone kojima se oblikuju javne politike), te kontrolna i nadzorna (nadzire provođenje javnih politika i kontrolira izvršnu vlast različitim ustavnim i institucionalnim mehanizmima). Parlamenti pored različitih uloga u političkom sistemu imaju svoju strukturu. Strukturu parlamenta određuje broj poslanika/članova parlamenta i broj parlamentarnih domova. Jednodomni (unikameralni) parlamenti se obično javljaju u unitarnim, etnički homogenim državama (mada ne nužno, npr. Francuska), a dvodomni (bikameralni) u složenim državama (federacije i savezne države). U dvodomnim parlamentaranim sistemima donji dom je u pravilu veći i osigurava političku predstavljenost cijelog stanovništva. Gornji domovi su u složenim državama domovi teritorijalnog predstavništva (Njemačka, SAD, Ruska Federacija...). Gornji dom predstavlja posebne, teritorijalno određene društvene grupe (savezne države u SAD, pokrajine u Njemačkoj, kantone u Švicarskoj, subjekte Ruske Federacije itd.) Članovi donjeg, predstavničkog doma se biraju po principu "jedan čovjek - jedan glas”. Izbor članova gornjeg doma je različit, od nasljednog prava, direktnih izbora, imenovanja, delegiranja itd. U parlamentarnim demokratijama od broja domova mnogo su 
važniji odnosi među njima u procesu političkog odlučivanja. Domovi mogu imati jednake ovlasti (npr. Bosna i Hercegovina - Dom naroda i Predstavnički dom ili SAD (Predstavnički dom i Senat). U tom slučaju se radi o simetričnim parlamentarnim sistemima. U nekim političkim sistemima domovi imaju podijeljene ovlasti ili nejednako podijeljene ovlasti, npr. Japan ili Francuska. U tom slučaju je riječ o asimetričnim parlamentarnim sistemima. U liberalnim parlamentarnim demokratijama donji dom je obično veći, ima posebnu odgovornost za budžet, forum je za predstavljanje glavnih zakonskih prijedloga i u većini zemalja "..ima pravo da prevaziđe veto ili amandman drugog (gornjeg) doma.” (Haggue i Harrop, 2014:394) Ta činjenica potvrđuje primarnost i supremaciju individualnih građanskih prava $\mathrm{i}$ interesa u odnosu na kolektivna. Broj domova u parlamentarnim sistemima je uslovljen razvojem i prirodom političkog sistema svake države, njenim specifičnim društveno - historijskim karakteristikama, a u konačnici i vizijom same demokratije. Najveći nedostatak dvodomnih paralementarnih sistema se javlja onda kada ideološki suprotstavljene parlamentarne većine nemaju sposobnost postizanja konsenzusa u procesu političkog odlučivanja. Takvi odnosi mogu u potpunosti blokirati politički proces oblikovanja javnih politika, a time i društveno - ekonomski razvoj. To u praksi dovodi i do neprimjerenog jačanja izvršne vlasti, krize parlamentarizma, destabilizacije cijelog političkog sistema i cjeline društvenih odnosa.

Zakonodavno tijelo je obično najbrojnije među primarnim granama vlasti. Njegova veličina u pravilu zavisi od veličine populacije određene države. Veličina parlamenta ne govori o njegovoj snazi u političkom procesu, ulozi u političkom sistemu ili društvenom značaju. Upravo veliki parlamenti često nemaju sposobnost kohezivnog djelovanja. ${ }^{3}$ Velika zakonodavna tijela je lakše politički kontrolirati od strane političkih stranaka ili je njihov rad pod dominacijom uticaja birokratskih struktura i parlamentarnih odbora/komsija. Sa druge strane, mali parlamenti se suočavaju sa deficitom legitimiteta jer ne mogu predstavljati sve građane ili posebne društvene grupe (socijalne, etničke ili religijske manjine itd.). Ne postoji jednostavna ili opće prihvaćena formula za određivanje veličine parlamenta. Iskustva drugih država mogu pomoći u oblikovanju ideja za promjenu ovog aspekta strukture Parlamentarne skupštine Bosne i Hercegovine. Pri tome je posebno važan donji dom koji predstavlja sve građane.

\footnotetext{
${ }^{3}$ Nacionalni narodni kongres Kine ima gotovo 3000 poslanika i pod potpunom je kontrolom vladajuće Komunističke partije. Drugi primjer je Evropski parlament, kao jedino zakonodavno tijelo u svijetu koje postoji na nadnacionalnom nivou, a bira se neposredno od strane građana država članica EU. Lisabonskim ugovorm iz 2009. godine je utvrđeno da može imati najviše 750 poslanika.
} 
Elmir Sadiković: Demokratska tranzicija i izborni sistem u Bosni i Hercegovini: ideje za jačanje predstavničke...

Tabela 1. Stanovništvo i veličina Donjeg doma4 (Caramani, 2013:132)

\begin{tabular}{lrrr}
\hline Zemlja & Stanovništvo & Veličina & Zastupnik na broj građana \\
\hline Austrija & 8.023 .000 & 183 & 43.842 \\
\hline Belgija & 10.170 .000 & 150 & 67.800 \\
\hline Bosna i Hercegovina & 3.531 .159 & 42 & 84.075 \\
\hline Češka Republika & 10.321 .000 & 200 & 51.605 \\
\hline Danska & 5.250 .000 & 179 & 29.300 \\
\hline Finska & 5.105 .000 & 200 & 25.525 \\
\hline Francuska & 58.040 .000 & 577 & 100.589 \\
\hline Grčka & 10.539 .000 & 300 & 35.130 \\
\hline Hrvatska & 4.784 .265 & 160 & 29.901 \\
\hline Italija & 57.460 .000 & 630 & 91.206 \\
\hline Njemačka & 83.536 .000 & 598 & 139.692 \\
\hline Poljska & 38.643 .000 & 460 & 84.007 \\
\hline Rusija & 148.178 .000 & 450 & 329.284 \\
\hline SAD & 301.102 .000 & 435 & 6.921 .188 \\
\hline Slovačka & 5.374 .000 & 150 & 35.827 \\
\hline Španjolska & 39.181 .000 & 350 & 111.946 \\
\hline Srbija & 7.186 .862 & 250 & 17.967 \\
\hline Slovenija & 2.050 .189 & 90 & 22.779 \\
\hline Švicarska & 7.207 .000 & 200 & 113.607 \\
\hline Turska & 62.484 .000 & 550 & 850 \\
\hline Ujedinjeno Kraljevstvo & 58.490 .000 & & \\
\hline & & 350 & \\
\hline
\end{tabular}

Komparativnom analizom ukupne populacije i broja zastupnika u Donjem (predstavničkom) domu izdvojenih nacionalnih parlamenata dolazimo do spoznaje da država Bosna i Hercegovina u odnosu na druge države i veličinu populacije ima nesrazmjerno mali donji (predstavnički) dom parlamenta. Jedan zastupnik predstavlja/zastupa interese čak 84.075 građana. Jedna od nužnih izmjena izbornog zakona Bosne i Hercegovine bi morala obuhvatiti povećanje broja zastupnika u Predstavničkom domu. Time bi interesi građana bili bolje zastupljeni. Uspostavila bi se snažnija veza između birača i političkih predstavnika u izbornim jedinicama, te njihova odgovornost prema biračima. Efektivna uloga parlamenta pored veličine zavisi i od brojnih drugih

\footnotetext{
${ }^{4}$ Podaci za Sloveniju, Hrvatsku, Srbiju i Bosnu i Hercegovinu se ne nalaze u izvornoj tabeli. Posebno su uvršteni za potrebe komparacije veličine Predstavničkog doma Paralamentarne skupštine Bosne i Hercegovine sa parlamentima država u regiji.
} 
varijabli. Neke od njih su: broj zasijedanja tokom godine, dodatna "vanjska" zaposlenja članova parlamenta, procenat smjene članova parlamenta u izbornom procesu, opšti kvalitet članova parlamenta, procedure parlamentarnog odlučivanja itd. Predstavnička demokratija je po sebi zahtjevnija od drugih režima vlasti jer se temelji na aktivnoj političkoj participaciji različitih subjekata, što je opet u korelaciji sa dostignutim nivoom političke kulture u svakoj zemlji. U višestranačkim parlamentarnim sistemima efikasnost rada svakog parlamenta je pored institucionalno-pravne i formalno-proceduralne osnove, primarno ovisna od sposobnosti parlamentarnih političkih subjekata da postižu konsenzus u procesu političkog odlučivanja.

\section{Uvod u historiju parlamentarizma u Bosni i Hercegovini}

Bosna i Hercegovina je u svom višestoljetnom razvoju, neovisno o svom državno - pravnom statusu, imala različite institucije i kontinuitet političkog predstavljanja naroda. Postojala je kao srednjevjekovna država i kao pravno odvojena i definirana provincija tokom četiri stoljeća osmanske vlasti (15631878). Zadržala je poseban status i pod austrougarskom vlašću (1878-1918), a i dok je bila dio zajednice jugoslovenskih država (1918-1992). Kao integralni teritorij Bosna i Hercegovina je u svakom historijskom periodu imala i razvijala svoju državnost. (Sadiković, 2019) Nositelji državnosti Bosne i Hercegovine su bili "parlamenti”, sa strukturom i funkcijama koje su bile primjerene datim društveno - historijskim okolnostima. Snažan pokazatelj državno - pravnog subjektiviteta srednjevjekovne Bosne je njen srednjevjekovni parlament - stanak, koji je posebno značajnu ulogu dobio nakon smrti Tvrtka I Kotromanića 1391. godine. U srednjevjekovnoj bosanskoj državi, "stanak" se prvi put spominje u povelji bana Tvrtka I Kotromanića iz 1354. godine. Činila ga je krupna vlastela, što je bilo tipično za sve evropske države u srednjem vijeku (staleško predstavništvo). Struktura stanka kao autentičnog segmenta državno - pravne tradicije srednjevjekovne Bosne, kojeg je pored kralja (od 1377. godine) kao simbola države činila bosanska vlastela, pokazuje da je Bosna u tom periodu bila tipična staleška monarhija. U vremenu osmanske vladavine (1463-1878) povremeno se javljaju zemaljski organi (Bosanski divan, Ajansko vijeće, Vilajetska skupština). Činili su ih namjesnici i administrativni službenici osmanske vlasti. Ti organi su imali savjetodavnu ulogu, bez stvarnih nadležnosti u modernom shvatanju parlamenta kao predstavničkog tijela. U vremenu Austro-Ugarske uprave (1878-1918) osnivaju se prve političke stranke, organizirane na etno-konfesionalnoj osnovi. Nakon 
aneksije 1908. godine Bosna i Hercegovina je došla pod puni suverenitet Austro - Ugarske monarhije. Austro - ugarska vlada je 1910. godine donijela Ustav, odnosno Zemaljski štatut za Bosnu i Hercegovinu i za njega vezane zakone, uključujući i Izborni zakon. (Ibrahimagić, 1999:40) Usvojeni Ustav koji je imao cilj da osigura socijalnu i konfesionalnu strukturu bosanskog društva nije bitno promijenio upravnu strukturu Bosne i Hercegovine. Uvedene su tri nove političke institucije: Sabor, Zemaljski savjet i kotarska vijeća. Sabor je bio konstituiran kombinacijom vjerskog, socijalnog i virilističkog sistema. U njemu su bili predstavljeni samo interesi određenih društvenih slojeva (zemljišni veleposjednici, bogata buržoazija i sveštenstvo). Uz sva demokratska ograničenja, u tom vremenu se stvaraju prvi oblici savremenog (stranačkog) parlamentarizma u Bosni i Hercegovini. Bosna i Hercegovina je zadržala neke oblike državnosti u Kraljevini Srba Hrvata i Slovenaca. Imala je Zemaljsku vladu za Bosnu i Hercegovinu koja je bila odgovorna centralnoj vladi u Beogradu. Osnivanje Zemaljskog antifašističkog vijeća Bosne i Hercegovine (ZAVNOBiH) u vremenu antifašističke borbe u II Svjetskom ratu (1941-1945) je imalo poseban historijski značaj za razvoj parlamentarne/predstavničke demokratije. Njegovo formiranje kao predstavničkog tijela i kao nosioca vlasti predstavljalo je bitan faktor izgradnje savremene bosanskohercegovačke državnosti. Na Drugom zasjedanju ZAVNOBiH-a u Sanskom Mostu 30. juna, 1. i 2. jula 1944. godine ZAVNOBiH-a postaje najviše zakonodavno i izvršno narodno predstavničko tijelo Bosne i Hercegovine. Na trećem Trećem zasjedanju ZAVNOBiH-a u oslobođenom Sarajevu 26. aprila 1945. godine, posebnim zakonom ZAVNOBiH je pretvoren u Narodnu skupštinu Bosne i Hercegovine. U uslovima jednostranačkog političkog sistema od 1945. do 1990. godine razvijao se specifičan oblik delegatskog, klasno-socijalnog i komunalno-teritorijalnog političkog predstavljanja. (Arnautović, 2009:209) Usvajanjem amandmana na ustav SR Bosne i Hercegovine u julu 1990. godine stvorene su ustavne pretpostavke za uvođenje višestranačkog političkog sistema i održavanje prvih višestranačkih izbora. Skupština SR Bosne i Hercegovine je nakon prvih višestranačkih izbora 1990. godine, ustavnim amandmanima bila organizirana u dva vijeća: Vijeće građana sa 130 poslanika i Vijeće općina u koje je svaka općina i gradska zajednica birala po jednog poslanika. Time je prvi put u historiji Bosna i Hercegovina dobila bikameralnu strukturu parlamenta. U cjelini gledano Bosna i Hercegovinu je od srednjeg vijeka do savremenog vremena imala različite institucionalne oblike političkog predstavništva. Kao heterogena etnička i socijalna struktura od prvih višestranačkih izbora 1990. godine 
suočava se sa izazovom razvoja stabilnog liberalno-demokratskog političkog predstavništva u okvirima političkog pluralizma.

\section{Kriza parlamentarizma i parlamentarne demokratije u "postdejtonskoj" Bosni i Hercegovini}

Izvršna vlast liberalnih demokratija dijeli se na osnovne tri grupe: predsjedničku, polupredsjedničku i parlamentarnu. Tri osnovne institucionalne forme se zasnivaju na različitim ustavnim mehanizmima podjele vlasti i kontrole izvršne vlasti. Prema Ustavu, Bosna i Hercegovina ima zakonodavnu, sudsku i izvršnu vlast. Institucije Bosne i Hercegovine koje su ustanovljene Ustavom Bosne i Hercegovine su: Parlamentarna skupština BiH, Predsjedništvo $\mathrm{BiH}$, Vijeće (savjet) ministara, Ustavni sud $\mathrm{BiH}$ i Centralna banka $\mathrm{BiH} .{ }^{5}$ Zakonodavnu vlast vrši Parlamentarna skupština Bosne i Hercegovine, koju čini Predstavnički dom i Dom naroda. Izvršni organi vlasti su Predsjedništvo Bosne i Hercegovine, kao kolektivni šef države i Vijeće ministara Bosne i Hercegovine. Sudsku vlast vrši Ustavni sud Bosne i Hercegovine, a 2002. godine je osnovan Sud Bosne i Hercegovine. Dualizam izvršne vlasti se ogleda u institucijama Predsjedništva i Vijeća ministara. Odnosi institucija izvršne i zakonodavne vlasti sadrže ustavne elemente parlamentarnog i (polu)predsjedničkog političkog sistema. U parlamentarnim političkim sistemima izvršna vlast može smijeniti zakonodavnu (raspustiti parlament i raspisati nove izbore). Mandati dvije institucije (Predsjedništva i Parlamentarne skupštine) su fiksirani. Nijedna institucija ne može smijeniti drugu. Predsjedništvo se bira neposredno, ima značajna ustavna ovlaštenja i imenovanjem mandatara sudjeluje u procesu izbora Vijeća ministara. Neposredan izbor predsjednika (u slučaju Bosne i Hercegovine Predsjedništva kao kolektivnog šefa države) je bitno strukturno obilježje predsjedničkog sistema vlasti. Vijeće ministara ima dvostruku odgovornost prema Predsjedništvu kao kolektivnom šefu države i prema Parlamentarnoj skupštini kao zakonodavnom tijelu. Ukoliko Predsjedništvo izglasa nepovjerenje predsjedavajućem Vijeća ministara u režimu je ostavke. Izglasavanje nepovjerenja u Predstavničkom domu Parlamentarne skupštine podrazumijeva smjenu Vijeća ministara. Dom

\footnotetext{
${ }^{5}$ Centralna banka BiH jedina je odovorna za izdavanje novca i monetranu politiku u Bosni i Hercegovini. Radom Centralne banke rukovodi Upravni odbor koji ima četiri člana koje imenuje Predsjedništvo BiH. Dva člana (Bošnjak i Hrvat) dolaze iz Federacije BiH i dijele jedan glas u Upravnom odboru. Jedan član (Srbin) dolazi iz Republike Srpske a četvrtpg člana imenuje Međunarodni monetrani fond u konsultaciji sa Predsjedništvom BiH i on ima funkciju guvernera ove institucije. Član VII. Ustava Bosne i Hercegovine.
} 
naroda se sastoji od petnaest delegata, odnosno pet Bošnjaka i Hrvata iz entiteta Federacija BiH i pet Srba iz entiteta Republika Srpska. Bošnjačke i hrvatske delegate bira Dom naroda Parlamenta Federacije BiH. Srpske delegate bira Narodna skupština Republike Srpske. Kvorum Doma naroda čini devet članova, s tim da su prisutna najmanje tri bošnjačka, srpska i hrvatska delegata prilikom odlučivanja. Dom naroda mogu raspustiti Predsjedništvo Bosne i Hercegovine ili sam dom. Predstavnički dom ima četrdeset dva člana. Dvije trećine, odnosno dvadeset i osam članova se bira sa područja entiteta Federacija $\mathrm{BiH}$ a jedna trećina, odnosno četrnaest sa područja entiteta Republika Srpska. Prema Ustavu nadležnosti Parlamentarne skupštine Bosne i Hercegovine su: donošenje zakona; odlučivanje o izvorima i iznosu prihoda za institucije i međunarodne obaveze Bosne i Hercegovine; usvajanje budžeta institucija Bosne i Hercegovine; ratifikacija međunarodnih ugovora i druga pitanja koja su neophodna da se provedu njene dužnosti ili koja su joj dodijeljena zajedničkim sporazumom entiteta. Zakonodavne odluke moraju biti odobrene od strane oba doma Parlamenta u istovjetnom tekstu. Pored zakonodavne, važna funkcija Parlementarne skupštine Bosne i Hercegovine je kontrolna. Vijeće ministara je odgovorno Parlamentarnoj skupštini za izvršenje budžeta, politike i zakona. Navedeni institucionalni izbor parlamentarno-predsjedničkog sistema vlasti je karakterističan za tranzicijske zemlje koje prolaze period kriza i konsolidacije demokratskih institucija vlasti. Zasniva se na pretpostavci da se “...objedinjavanjem neposrednih izbora predsjednika osigurava stabilnost izvršne vlasti a istovremeno i fleksibilnost parlamentarne vlade." (Kasapović, 1997:11)

Promatrana na formalno-pravnoj osnovi Parlamentarna skupština Bosne i Hercegovine ima sve klasične nadležnosti koje pripadaju parlamentu kao najvišem zakonodavnom tijelu u svakoj državi. Drugo pitanje je u kojoj mjeri ostvaruje ustavom određene nadležnosti i predstavlja stvarni centar političke moći. Pitanje parlamentarne suverenosti u uloge Parlamentarne skupštine Bosne i Hercegovine jedno je od najvažnijih pitanja postdejtonskog političkog i demokratskog razvoja Bosne i Hercegovine. U kojoj mjeri je Parlamentarna skupština Bosne i Hercegovine autentični izraz narodne volje, nositelj suverenosti, centar razumne rasprave i odlučivanja, te stvarno kontrolno tijelo izvršne vlasti. (Ne) moć najvećeg zakonodavnog organa u državi se može promatrati kroz osnovne karakeristike parlamentarizma. Da li je Parlamentarna skupština Bosne i Hercegovine aktivna i uticajna? Kakav je njen odnos sa organima izvršne vlasti? Iskustvo postdejtonskog politčkog razvoja Bosne i Hercegovine pokazuje da funkcionalan parlamentarizam pretpostavlja odgovarajući stepen društveno - ekonomskog razvoja, razvijeno civilno društvo 
i što je posebno bitno, konsenzus i integralnost unutar same parlamentarne elite. U Bosni i Hercegovini te pretpostavke nisu ostvarene. Iz tog razloga je stvarna moć odlučivanja izmještena iz parlamenta. (Pejanović, 2011) Treba imati u vidu da parlament teško može imati veliki politički značaj u uslovima općeg nepovjerenja građana prema institucijama političkog sistema. Promatrana na institucionalno-proceduralnoj ravni Parlamentarna skupština Bosne i Hercegovine ne pokazuje sposobnost transformacije prijedloga izvršne vlasti i donošenja zakona na temelju autentične, izvorne moći. Zapravo se u konstelaciji političkih snaga javlja kao sljedbenik i proizvod birokratiziranih stranačkih i vaninstitucionalnih centara političke moći. To umanjuje osnovnu funkciju parlamenta - donošenje zakona. ${ }^{6}$ Slabosti parlamentarizma u Bosni i Hercegovini možemo detaljnije elaborirati kroz tri različita ali usko povezana pristupa: teoriju predstavljanja; odnos parlamentarne i izvršne vlasti i kroz karakter partijskog/stranačkog grupisanja. (Pavlović, Orlović, 2007) Teorije predstavljanja možemo svrstati u liberalno demokratske i kolektivističke. Parlamentarizam u Bosni i Hercegovini je zasnovan na dominaciji kolektivističkog etno-teritorijalnog političkog predstavljanja. Artikulacija građanskih interesa u parlamentarnoj raspravi je podređena etničkim interesima. Proceduralni mahanizmi blokade (enititetske u Predstavničkom domu i etničke u Domu naroda) u procesu političkog odlučivanja umanjuju osnovnu funkciju parlamenta - donošenje zakona. Drugi pristup obuhvata odnos izvršne i zakonodavne vlasti, kao jedno od najznačajnijih pitanja političke teorije i prakse. Način političkog organiziranja u Bosni i Hercegovini i institucionalna pravila u stvarnosti dovode do stranački determinisanog odnosa članova izvršne i zakonodavne vlasti. Međutim, to je tipično za sve, posebno evropske, parlamentarne sisteme u kojima dolazi do sjedinjenja izvršne i zakonodavne vlasti. Međutim, institucionalizirani konsesualni model demokratije u Bosni i Hercegovini (za razliku od većinskog vestminsterskog) parlamentu daje zakonsku i proceduralnu osnovu za aktivniju ulogu u političkom procesu. Problem je u tome što je u Bosni i Hercegovini sve izraženija tendencija prezindezijalizacije izvršne vlasti. Iako su ovlaštenja izvršne vlasti prema zakonodavnoj ograničena, u smislu da ne može raspustiti parlament ${ }^{7}$, stabilnost

\footnotetext{
${ }^{6}$ Prema izvještaju Centra civilnih inicijativa (CCI): u mandatnom periodu 2002-2006 usvojeno je 229 zakona; 2006-2010 usvojeno je 170 zakona; 2010-2014 usvojeno je 85 zakona; 2014-2018 usvojeno je 59 zakona, a čak 58 predloženih zakona nije dobilo potrebnu parlamentarnu većinu. Mandatno izvješće o monitoringu rada Paralmentarne skupštine BiH 12. 10. 2014-30. 6. 2018. Preuzeto s: http://www.cci. ba/monitoring/1/7/1.html. 6. 11. 2020.

${ }^{7}$ U Bosni i Hercegovini ne postoji institut vanrednih izbora, što je jedinstven primjer u parlamentarnim političkim sistemima
} 
parlamenta kao institucije sa druge strane umanjuje politički motiv članova parlamenta da u vremenu političkih kriza odlučnije djeluju prema stranačkim elitama. Zakonodavne, legitimacijske i deliberativne funkcije parlamenta su nedostatne, što umanjuje samu vrijednost parlamentarizma. Partijski centralizam i partijska disciplina umanjuju individaualnu moć zastupnika u parlamentu. Pri tome ne treba zanemariti ni lične interese zastupnika koji kroz partijsku lojalnost osiguravaju pozicije u kadrovskoj politici partija. Lojalnost poslanika partijskom lideru je najbolja kvalifikacija za izbor na neku politčko-izvršnu funkciju. Međutim, to nije samo obilježje parlamentarizma u Bosni i Hercegovini. Slični fenomeni se javljaju i u evropskim zemljama sa dugom parlamentarnom tradicijom. Neki teoretičari smatraju da parlamenti svoju ulogu najbolje ostvaruju u "...političkim sistemima u kojima su partijske organizacije relativno heterogene (SAD) ili u kojima izborni sistem djeluje u uslovima velikog broja konkurirajućih partija (Senat u Italiji)." (Vasović, 2007: 20) Slabosti stranački kontroliranog parlamentarizma u Bosni i Hercegovini pokazuju da on još uvijek ne funkcionira kao suvereni i odlučujući faktor političkog odlučivanja. Partokratija i interesi birokratiziranih stranačkih elita devalviraju ključne institucije političkog sistema, u koje svakako spadaju parlament i parlamentarizam. Partije su postale vrhovne i ključne institucije političke vlasti, a u nedostatku parlamentarnog nadzora, izvršna vlast stvarni centar političke moći.

\section{Ideje za unapređenje uloge institucije Parlamentarne skupštine Bosne i Hercegovine}

Bosanskohercegovački konstitucionalizam oblikovan intervencijom međunarodne zajednice u uslovima rata ne uspijeva rekonstruirati demokratsku legitimnost državnih institucija, a time i institucije Parlamentarne skupštine u uslovima mira. Politička (ne)kultura, nizak socio-ekonomski razvoj, okolnosti institucionalizacije cjeline političkog sistema u (post)konfliktnom bosanskohercegovačkom društvu su značajni faktori koji ograničavaju razvoj parlamentarizma i parlamentarne demokratije u Bosni i Hercegovini. Ne ulazeći u društveno historijske okolnosti institucionalnog oblikovanja parlamentarne demokratije, cjeline ustavnog i izbornog sistema u Bosni i Hercegovini, u nastavku ćemo se zadržati na instituciji Parlamentarne skupštine, kao najvišem zakonodavnom tijelu. Idejni tvorac savremene predstavničke demokratije J. S. Mill je smatrao da su institucije ljudsko djelo i svoj opstanak duguju volji. Ne funkcioniraju same, nego ih čovjek održava. Da bi opstale trebaju ljudsko 
prihvaćanje, volju da se održavaju, te volju i sposobnost da čine ono što se od njih traži. (Mill, 1998). Polazeći od navedenih teza u nastavku teksta ćemo elaborirati ideje za unapređenje društvene uloge i političkih funkcija institucije Parlamentarne skupštine Bosne i Hercegovine. Pri tome su posebno važni aspekti tipa izbornog sistema, strukture i načina konstituisanja najvišeg zakonodavnog tijela. Iskustva razvoja drugih država pokazuju da demokratske političke institucije mogu mijenjati i političku kulturu svake zemlje. Iz tog razloga polazimo od stajališta da se formalno-pravnim reformama kroz izmjenu izbornog zakonodavstva mogu stvoriti pretpostavke za unapređenje uloge institucije Parlamentarne skupštine Bosne i Hercegovine.

Odluka o izboru vrste izbornog sistema je jedna od najznačajnijih ustavnopravnih i političkih odluka svake države. Način "pretvaranja" glasova birača u političke mandate je temelj konstituiranja predstavničkih tijela i institucija. Izborni sistem je jedan od ključnih elemenata za razumijevanje organizacijskih i funkcionalnih karakteristika stranačkog/partijskog sistema. (Deren - Antoljak, 1992) Izborni sistem utiče na oblikovanje partijskog sistema, broj partija, unutrašnje odnose u partijama, kao i na "koaliciono ponašanje partija" što je iznimno važno sa stanovišta funkcioniranja i razvoja parlamentarizma. (Goati, 2008:308) U političkoj teoriji je do sredine 20. stoljeća bilo dominantno mišljenje da proporcionalni izborni sistemi dovode do velikog broja partija, a većinski do dvopartijskog ili do sistema sa malim brojem partija, jer smanjuju partijsku parlamentarnu snagu u odnosu na izborni rezultat. Od sredine 50-ih godina 20. stoljeća razvija se kritička teorija prenaglašavanja uloge izbornog sistema na strukturu političkog pluralizma. Umjesto jednosmjernog uticaja izbornog sistema na partije ukazuje se i na uticaj političkih partija na izborni sistem. Brojni primjeri, posebno u postkomunističkim zemljama, pokazuju kako su dominantne partije, vodeći se svojim interesima, konsenzusom usvojile izborne zakone i odredile pravila razvoja partija i oblikovanja partijskog sistema. Sartori prepoznaje povezanost izbornog sistema i karaktera političkog pluralizma, ali osporava pojednostavljen pristup da proporcionalni izborni sistem nužno dovodi do sistema sa velikim brojem partija. U etnički, religiozno i kulturno heterogenim društvima sa izraženim socijalno - političkim rascjepima, teritorijalno grupisane zajednice glasaju za svoje partije bez obzira na tip izbornog sistema. (Sartori, 2003) Izborni sistemi snažno utiču na rezultate izbora a time i na formiranje parlamentarnih stranačkih većina. Veza između izbornog i partijskog sistema nesumnjivo postoji, ali je treba promatrati u korelaciji te dvije varijable. Tip proporcionalnog izbornog sistema koji se u Bosni i Hercegovini primjenjuje u izboru 
zakonodavnih tijela ima svoje opravdanje. Drugo pitanje je koliko taj sistem izbora doprinosi političkoj (ne)stabilnosti i da li bi primjena drugog izbornog sistema dovela do političke stabilnosti? Proporcionalni izborni sistemi osiguravaju pravedniju raspodjelu mandata i uslovljavaju široke koalicijske vlade. Institucionalizacija proporcionalnog izbornog sistema i parlamentarnog tipa vlasti u pravilu vodi konsocijacijskom ili konsenzualnom modelu demokratije. Većinski izborni sistemi (pobjednik uzima sve) tendiraju dvostranačkim ili sistemima sa manjim brojem partija te shodno tome jednostranačkim vladama. I jedan i drugi sistem imaju svoje prednosti i nedostatke, ali ih se valja promatrati $u$ širem nacionalnom kontekstu. Politička iskustva drugih država pokazuju da tipovi izbornog sistema (većinski, proporcionalni ili mješoviti) nisu ključni elementi koji utiču na političku i društvenu stabilnost.

U elaboraciji predstavničke funkcije Parlamentarne skupštine Bosne i Hercegovine posebno značajno je pitanje izbornih pravila i procedura koje (ne)osiguravaju adekvatnu političku predstavljenost. Predstavnički dom Parlamentarne skupštine sa 42 zastupnika nesrazmjerno mali u odnosu na druge države sa približnom veličinom populacije. Procedure koje osiguravaju legitimnu političku predstavljenost parlamenta podrazumijevaju osnovne demokratske standarde za poštene i slobodne izbore (birački spiskovi, registracija stranaka, izborni postupak..). ${ }^{8}$ Demokratski deficit Parlamentarne skupštine Bosne i Hercegovine se ogleda i u načinu izbora Doma naroda. Onemogućavanje predstavljanja građana koji ne pripadaju konstitutivnim narodima u ovom domu je u suprotnosti sa Međunarodnim paktom o građanskim i političkim pravima.

Podjela na izborne jedinice je najvažniji element svakog izbornog sistema, a često se definira "kao izborni sistem u užem smislu." (Arnautović, 2009:637) Zbog toga je važno elaborirati strukturu izbornih jedinica za Predstavnički dom Parlamentarne skupštine Bosne i Hercegovine. Članove Predstavničkog doma biraju građani neposredno u svakom entitetu. Od dvadeset i osam članova neposredno izabranih u entitetu Federacija $\mathrm{BiH}$, dvadeset i jedan se bira u pet izbornih jedinica, a sedam su kompenzacijski mandati. Od četrnaest neposredno izabranih članova sa prostora entiteta Republika Srpska, devet se bira u tri izborne jedinice a pet su kompenzacijski mandati. Kompenzacijski mandati se političkim subjektima dodjeljuju na osnovu

\footnotetext{
${ }^{8}$ Međunarodni pakt o građanskim i političkim pravima u članu 25. navodi: "Svaki građanin ima pravo i mogućnost da učestvuje u upravljanju javnim poslovima, neposredno ili preko izabranih predstavnika; da bira i da bude biran; da bude primljen pod opštim i jednakim uslovima u javne službe službe svoje zemlje. Način izbora Doma naroda je u suprotnosti sa Međunarodnim paktom o građanskim i političkim pravima, jer onemogućava predstavljanje građana koji ne pripadaju konstitutivnim narodima.
} 
ukupnog broja dobijenih glasova na prostoru entiteta. Cenzus za političke subjekte u višemandatnim jedinicama biranih po proporcionalnom izbornom sistemu je 3\%, a za kompenzacijske mandate 5\%. U njihovoj raspodjeli mogu sudjelovati samo političke partije i koalicije, ali ne i nezavisni kandidati. Kompenzacijskim mandatima se zapravo formalno osigurava ravnopravno učešće svih etničkih zajednica u najvišem zakonodavnom tijelu.

Karta 1. Izborne jedinice za zastupnički/predstavnički dom Parlamentarne skupštine BiH (Izvor: Centralna izborna komisija BiH)

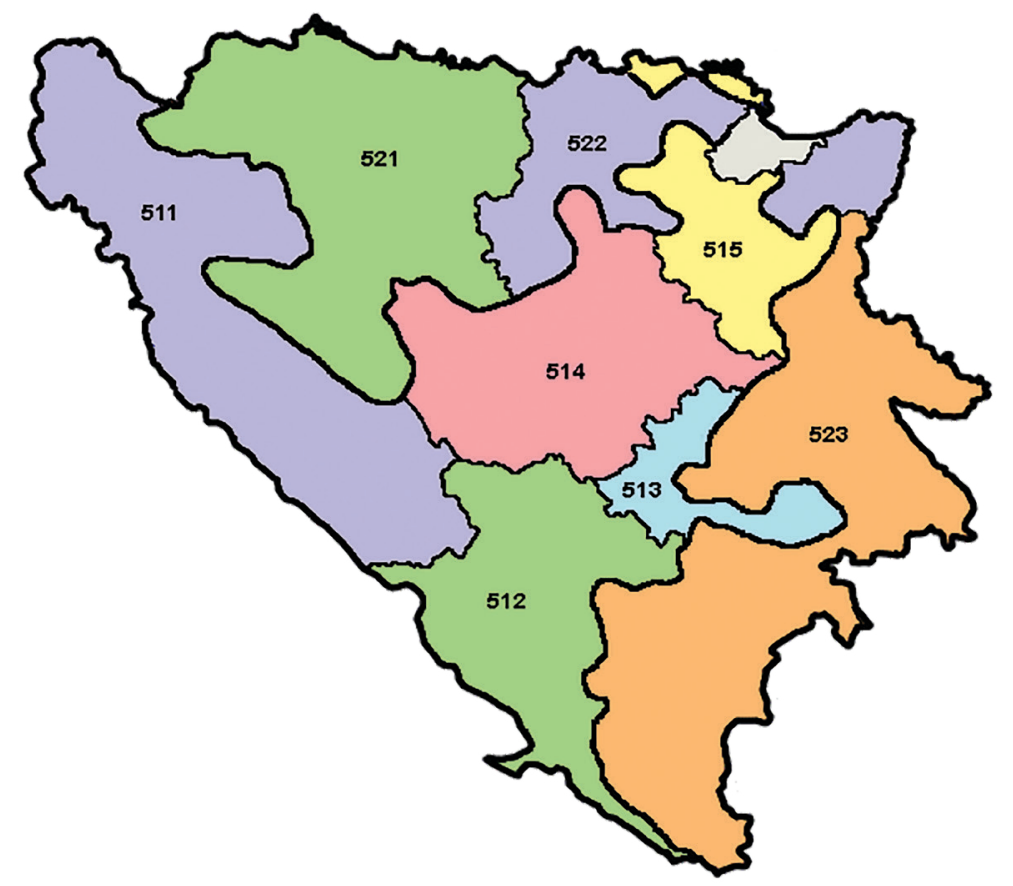

\begin{tabular}{ll}
\hline Federacija BiH & \\
\hline 511 izborna jedinica 1 & 3 zastupnika \\
\hline 512 izborna jednica 2 & 3 zastupnika \\
\hline 513 izborna jedinica 3 & 4 zastupnika \\
\hline 514 izborna jedinica 4 & 6 zastupnika \\
\hline 515 izborna jedinica 4 & 5 zastupnika \\
\hline Republika Srpska & \\
\hline 521 izborna jedinica 1 & 3 zastupnika \\
\hline 522 izborna jedinica 2 & 3 zastupnika \\
\hline 523 izborna jedinica 3 & 3 zastupnika \\
\hline
\end{tabular}


Kvorum u Predstavničkom domu čini većina svih članova izabranih u ovo tijelo, ali se zakonodavne odluke mogu usvojiti uz saglasnost najmanje jedne trećine glasova članova iz oba entiteta. Time je u zakonodavni postupak ugrađen princip entitetskog glasanja u Predstavničkom domu, što je jedinstven primjer u parlamentarnim političkim sistemima. Izbornim zakonom određene izborne jedinice za Predstavnički dom Parlamentarne skupštine Bosne i Hercegovine bitno utiče na činjenicu da se partijsko angažovanje u izbornom procesu kao "institucionalizovanom sukobu" (Goati, 2008:93) odvija duž neprirodnih entitetskih (etničkih) granica. Postojeća organizacija izbornih jedinica, nasuprot interesno - građanskom, pogoduje etno-nacionalnom stranačkom organiziranju. Naučni i stručni kriteriji u određenju granica izbornih jedinica su zanemareni. Velike promjene u demografskoj strukturi stanovništva Bosne i Hercegovine (iseljavanje i unutrašnje migracije), znatno povećanje biračkog tijela kroz pasivnu (automatsku) registraciju birača su društveni procesi koji sasvim izvjesno doveli do velike neravnoteže u broju birača između pojedinih izbornih jedinica, a time u pitanje ustavnost i legitimnost izbora. ${ }^{9}$ Zakonodavna tijela imaju zakonsku obavezu da svako četiri godine razmatraju granice izbornih jedinica. Prostorno-demografski okvir izbornih jedinica neophodno je revidirati u određenim vremenskim intervalima, barem nakon svakog popisa stanovništva. To je praksa koju primjenjuju sve evropske demokratske zemlje, koje u prosjeku toleriraju prag odstupanja od 5\% manje ili više birača u izbornim jedinicama. Izborne jedinice bi trebale činiti jedinice lokalne samouprave (općine i gradovi) koje su prirodno-geografski i ekonomski povezane. Nije realno očekivati konsenzus o promjeni granica izbornih jedinica na način da obuhvate prostor dva entiteta. Međutim, promjena postojećih izbornih jedinica koje su utvrđene 2001. godine je objektivna nužnost i u okviru postojeće administrativno - teritorijalne organizacije političke vlasti. Time bi se povećala funkcionalnost i reprezentativnost Parlamentarne skupštine. Moguća reforma načina izbora poslanika u Predstavničkom domu bi se mogla zasnovati na primjeni mješovitog izbornog sistema. Polovina članova bi se birala sistemom proporcionalne reprezentacije na nivou cijele zemlje, a druga polovina većinskim sistemom na nivou jednomandatnih regija. Suad Arnautović je stajališta da bi se time “...dao veći legitimitet regionalnim predstavnicima a istovremeno

\footnotetext{
${ }^{9}$ Ovaj pojava je u političkoj teoriji poznata kao "malapportionment" i predstavlja način narušavanja jednakosti biračkog prava Vidi: Matteo Žugaj i Stjepan Šterc (2016) Hrvatske izborne jedinice - postojeći nesklad i buduće promjene. Pilar: Časopis za društvene i humanističke studije. Vol XI. No 2. Zagreb. Str. 9 - 33 .
} 
ojačalo predstavništvo za sve građane.” (Arnautović, 2009:638). Obzirom na veliki broj državljana Bosne i Hercegovine koji žive u inostranstvu bilo bi smisleno razmotriti mogućnost osiguranja njihovog političkog predstavljanja. Posebnim političkim predstavljanjem dijaspore bi se uspostavila neposredna institucionalna veza između države i dijaspore, te stvorila osnova za korištenje tog velikog demografskog potencijala u ekonomskom, naučnom i svakom drugom razvoju Bosne i Hercegovine. To je praksa koju primjenjuju neke evropske zemlje (Hrvatska, Italija, Portugal i Francuska). Pitanje reprezentativnosti parlamenta je direktno vezano i za način izbora poslanika. Proporcionalni izborni sistem sa poluotvorenim listama potrebno je razmotriti. Uslov od 20\% preferencijalnih (ličnih) glasova od ukupnog broja glasova stranačke liste koje kandidat treba ostvariti da bi bio bio izabran umanjuje izbornu volju birača a stranačkim liderima i elitama daje alat da u procesu koncipiranja izbornih listi daju prednost određenim kandidatima. Ovaj model političkim strankama daje mogućnost da utiču u pozitivnom smislu na zastupljenost različitih, posebno marginaliziranih,društvenih grupa. Međutim, iskustvo izbora pokazuje da stranačke elite zakonom definirani cenzus koriste za vlastito političko pozicioniranje. Uvođenje otvorenih listi ukidanjem izbornog cenzusa od $20 \%$ za kandidate, ili smanjenjem na razumnu mjeru bi bila reforma koja bi doprinijela demokratizaciji izbornog procesa i institucije Parlamentarne skupštine Bosne i Hercegovine. Pitanje koje se takođe može problematizirati jesu kompenzacijski mandati. Radi se o mandatima koji se dodjeljuju političkim subjektima u onim izbornim jedinicama u kojima se ti subjekti prešli izborni prag od 3\%, ali nisu imali dovoljno glasova da osvoje redovni mandat. ${ }^{10}$ Zatvorene liste za kompenzacijske mandate (12 od 42) su još jedan mehanizam koji stranačke elite koriste za osiguranje mandata ukoliko u svojoj izbornoj jedinici ne mogu ostvariti dovoljan broj glasova. Iako kompenzacijski mandati nisu sporni sa stanovišta kompenzacije nedovoljne proporcionalnosti na entitetskom nivou koja nastaje sabiranjem rezultata za pojedine višečlane izborne jedinice ${ }^{11}$, i u ovom slučaju bi se trebao primjeniti sistem otvorenih listi. Pored toga, pitanje odnosa broja direktnih (30) i kompenzacijskih (12) mandata potrebno je preispitati, kao i način njihove dodjele. Dodjelom kompenzacijskih mandata sa državnog nivoa, umjesto sa nivoa entitetskih izbornih jedinica, bi se amortizirale međuetničke napetosti i potaklo

\footnotetext{
${ }^{10}$ Član 9.6. Izbornog zakona Bosne i Hercegovine. Službeni glasnik BiH, broj 23/1.

${ }^{11}$ Višečlana izborna jedinica podrazumijeva izbornu jedinicu u kojoj se bira više od jednog a manje od ukupnog broja predstavnika za pojedini nivo vlasti.
} 
snažnije organiziranje političkih stranaka na prostoru cijele zemlje umjesto dominantno u entitetskim prostornim okvirima. (Arnautović, 2009:640)

Jačanje nacionalne zakonodavne vlasti jedan je od institucionalnih mehanizama demokratizacije i kontrole neprimjerene dominacije izvršne vlasti. Reforma izbornog zakonodavstva koja bi doprinijela demokratizaciji i unapređenju funkcija i uloge institucije Parlamentarne skupštine Bosne i Hercegovine bi obuhvatila sljedeće aspekte:

- Povećanje broja zastupnika u Predstavničkom domu

- Parlamentarno predstavništvo građana u Domu naroda koji ne pripadaju konstitutivnim narodima

- Redefiniranje granica (prostornog obuhvata) izbornih jedinica

- Promjenu načina/sistema izbora zastupnika

- Parlamentarno predstavništvo bosanskohercegovačke dijaspore

- Parlamentarno predstavništvo nacionalnih manjina

Time bi se unaprijedila efikasnost institucije Parlamentarne skupštine u demokratskom procesu političkog predstavljanja, donošenja zakona i kontrole izvršne vlasti. Pluralizam interesa oblikovanog konstituiranjem parlamenta kroz navedene reforme bi doveo do promjena u broju parlamentarnih stranaka, polarizacije biračkog tijela na interesnoj a ne dominantno etničkoj osnovi, a time i do lakšeg formiranja postizbornih koalicija na programskoj osnovi. Stvorila bi se osnova za prevladavanje ključnog problema parlamentarne demokratije i državnog razvoja Bosne i Hercegovine, a to je pitanje konsenzusa. (Pejanović, 2013) Na kraju, ipak je važno isključiti determinirajuću ulogu izbornog sistema na politiku i političke procese. Efikasnost parlamenta u svakoj zemlji se ne može odvojiti od konkretnog političkog i društvenog konteksta. Liberalna parlamentarna demokratija počiva na principima narodne suverenosti, vladavine prava, podjele vlasti, zaštite manjina i opozicije, slobodnih izbora, aktivnog civilnog društva i zagarantovanih građanskih prava. Ostvarenje tih ideala je dug, težak i složen društveno historijski proces, posebno u zemlji heterogene etničke i socijalne strukture kakva je Bosna i Hercegovina.

\section{Zaključak}

Parlamentarna skupština Bosne i Hercegovine je kao najviše zakonodavno tijelo centralna institucija političkog sistema i jedina suverena vlast u državi. U vršenju osnovnih ustavnih nadležnosti: političkog predstavljanja, donošenja zakona i kontrole izvršne vlasti, Parlamentarna skupština ne ostvaruje svoju 
ulogu u punom kapacitetu. Nedostatak tradicije demokratskog parlamentarizma i nesposobnost stranačkih elita da postignu konsenzus o najvažnijim pitanjima razvoja države i društva umanjuju političku moć parlamenta kao centra političkog odlučivanja. U političkoj praksi to dovodi do neprimjerene dominacije izvršne vlasti i koncentracije stvarne moći u rukama birokratiziranih stranačkih elita. Reforme izbornog zakonodavstva mogu doprinijeti demokratizaciji institucije parlamenta i jačanju njegove uloge u političkom sistemu. Te reforme bi obuhvatile strukturalnu promjenu načina konstituiranja parlamenta: redefiniranjem granica izbornih jedinica; izmjenom načina izbora zastupnika primjenom sistema otvorenih listi; osiguranjem srazmjernog političkog predstavljanja marginaliziranih društvenih grupa i dijaspore. Time se mogu stvoriti osnove za jačanje interesno - građanskog političkog organizovanja i formiranja parlamentarnih koalicija na programskoj osnovi, a time i amortizirati etno-teritorijalni politički i društveni rascjepi.

\section{Bibliografija:}

Almond, Gabriel (2009). Komparativna politika danas, Univerzitet Crne Gore- Fakultet političkih nauka. Podgorica.

Arnautović, Suad (2009). Političko predstavljanje i izborni sistemu u Bosni i Hercegovini u XX stoljeću. Promocult. Sarajevo

Centralna izborna komsija $\mathrm{BiH}$, https://www.izbori.ba/rezultati/konacni/parlament_bih/index.htm, 09.10.2020.

Carmani, Daniele (2013). Komparativna politika, Zagreb: Fakultet političkih znanosti.

Centri civilnih inicijativa Mandatno izvješće o monitoringu rada Paralementarne skupštine BiH 12.10.2014 - 30. 6. 2018. Preuzeto s: http://www.cci.ba/monitoring/1/7/1.html. 6. 11. 2020.

Fejzić, Elvis (2016). Transformacija upravljanja državom. Fakultet političkih nauka. Sarajevo. Deren Antoljak, Štefica (1992). Izborni sistemi i Duvergerov zakon. Politička misao Vol. XXIX. No 2. str. 23-38. Zagreb. Preuzeto s: file:///C:/Users/Admin/Downloads/politicka_ misao_1992_2_23_38.pdf. 28.10.2020.

Goati, Vladimir (2008). Političke partije i partijski sistemi. Fakultet političkih nauka - Univerzitet Crne Gore. Podgorica

Hague, Rod (2013). Uporedna vladavina i politika. Fakultet političkih nauka. Beograd

Ibrahimagić, Omer (1999). Politički sistem Bosne i Hercegovine. Magistrat. Sarajevo.

Izborni zakon Bosne i Hercegovine Tehnički prečišćeni tekst). Službeni glasnik $\mathrm{BiH}$, broj 23/1. Preuzeto s: https://izbori.ba/Documents/documents/ZAKONI/Izborni_zakon_PRECISCENI_TEKST-bos.pdf, 27. 10. 2020.

Kasapović, Mirjana (1997). Parlamentarizam i prezidencijalizam u Istočnoj Europi. Politička misao, Vol XXXIV. br. 1. (5-20). Zagreb.

Međunarodni pakt o građanskim i političkim pravima. Preuzeto s: http://www.unhchr.ch/ $\mathrm{html} / \mathrm{menu3/b/a}$ _ccpr.htm, 4. 10. 2020.

Mill, John Stewart (1998). Razmatranja o predstavničkoj vladavini. Fakultet političkih nauka. Zagreb 
Orlović, Slaviša (2011). Challenges of representative democracy. ur. Milan Podunavac, State and democracy. Službeni glasnik, Fakultet političkih nauka. Beograd. str. 432- 456

Parlamentarna skupština Bosne i Hercegovine - monografija (2010) Edin Radušić... (et. al.), Sarajevo, Parlamentarna skupština BiH. Preuzeto s: https://www.parlament.ba/ 2. 10. 2020.

Pejanović, Mirko (2011). Instead of conclusion: Where does the destructive effect of the boogeyman of consensus in the parliamentary democracy of B\&H come from. In: ur. Milan Podunavac, State and democracy. Službeni glasnik, Fakultet političkih nauka. Beograd

Pejanović, Mirko (2013). Ogledi o državnosti i političkom razvoju BiH (treće dopunjeno izdanje). Šahinpašić. Sarajevo

Sabo, Kristian. Scitovski, Rudolf. Taler, Petar (2012). Ravnomjerna raspodjela birača po izbornim jedinicama temeljem matematičkog modela. Hrvatska komparativna javna uprava. Vol. 12. br. 1. str. 229-249. Zagreb. Preuzeto s: https://hrcak.srce.hr/index. php?show=clanak\&id_clanak_jezik=196026, 13. 10. 2020.

Sadiković, Elmir (2019). Subnacionalni konstitucionalizam i demokratija. Fakultet političkih nauka. Sarajevo.

Sartori, Đovani (2003). Uporedni ustavni inžinjering - strukture, podsticaji, ishodi. Filip Višnjić. Beograd.

Vasović, Vučina (2007). Savremeni izazovi parlamentarizma. Zbornik radova: Dileme i izazovi parlamentarizma. Ur. Vukašin Pavlović i Slaviša Orlović. Beograd: Konrad Adenauer Stiftung, Fakultet političkih nauka Univerziteta u Beogradu. str. 7 -44.

\section{Democratic Transition and Electoral Systems - Ideas for Strengthening the Representative Role of the Parliamentary Assembly of Bosnia and Herzegovina}

\section{Summary}

As the highest legislative body, the Parliamentary Assembly of Bosnia and Herzegovina is the central institution of the political system and the only sovereign authority in the state. In exercising its basic constitutional competencies: political representation, law-making and control over the executive, the Parliamentary Assembly does not fulfill its role in full capacity. The lack of democratic parliamentarism tradition and especially the inability of the party elites to reach consensus on the most important issues of the political and social development diminish the political power of parliament as a center of political decision-making. In political practice, this leads to inappropriate domination of the executive and the concentration of real power in the hands of bureaucratized political party elites. Reforms of electoral legislation can contribute to the democratization of the parliamentary institution and strengthen its role in the political system. These reforms would include a structural change in the way 
parliament is constituted by: redefining electoral boundaries; change the method of electing representatives by applying the open list system; to ensure a balanced political representation of marginalized social groups. This can create the basis for strengthening interest-civic political organization political behavior and at the same time amortize ethno-territorial political and social divisions. 